\title{
Economic Analysis of a Large UASB Reactor Producing Biogas from Baggase Wash Water
}

\author{
V. K. Jain1, Surinder S. Sambi², Surendra Kumar ${ }^{3 *}$, Shashi ${ }^{3}$ \\ ${ }^{1}$ Ministry of New and Renewable Energy, Government of India, New Delhi, India \\ ${ }^{2}$ School of Chemical Technology, Guru Gobind Singh Indraprastha University, Dwarka, India \\ ${ }^{3}$ Department of Chemical Engineering, Indian Institute of Technology Roorkee, Roorkee, India \\ Email: $\underline{\text { skumar@iitr.ac.in }}$
}

Received 27 December 2013; revised 26 January 2014; accepted 25 February 2014

Copyright (C) 2014 by authors and Scientific Research Publishing Inc.

This work is licensed under the Creative Commons Attribution International License (CC BY). http://creativecommons.org/licenses/by/4.0/

(c) $\underset{\mathrm{EY}}{\mathrm{Br}}$ Open Access

\begin{abstract}
This paper concerns with the treatment of bagasse wash water, which is generated after washing the stored bagasse before its use in the paper manufacture. The bagasse wash water, treated earlier in open lagoons, is now treated by the anaerobic process using UASB reactor. This study, based upon an operating unit, shows that the UASB reactor reduces COD of wash water by $85 \%-90 \%$, and results in significant emission reductions. Economic analysis carried out by using financial indicators such as DSCR, Payback period and IRR reveals very attractive rate of returns and thus, greatly reduces the risks in financing such projects by the financial institutions.
\end{abstract}

\section{Keywords}

UASB Reactor; Bagasse Wash Water; Biogas; Economic Analysis

\section{Introduction}

India is a large, and fast growing economy with a very low consumption of energy; average per capita consumption of electricity is $704 \mathrm{kWh}$ during 2008-09 against world average at $2300 \mathrm{kWh}$. Increased supply of energy particularly "Electricity" is needed for nurturing economic growth, for improving the quality of life and for increasing opportunities for development which will ultimately lead to raising India's human development index that compares poorly with several countries that are currently below the India's level of development [1] [2]. According to the Planning Commission projections, power generation capacity in the country must be increased to nearly 800 GW by 2031-32 from the current capacity of around 160 GW (inclusive of all captive plants). An

*Corresponding author.

How to cite this paper: Jain, V.K., et al. (2014) Economic Analysis of a Large UASB Reactor Producing Biogas from Baggase Wash Water. Journal of Sustainable Bioenergy Systems, 4, 68-74. http://dx.doi.org/10.4236/jsbs.2014.41007 
increasing percentage of this will have to come from renewables against over 66 percent of the total installed power generating capacity presently comes from fossil fuels mainly from coal [3].

Though, India is relatively low carbon economy by global comparison by two measures- $\mathrm{CO}_{2}$ emission per capita, and $\mathrm{CO}_{2}$ emission per Unit of GDP in PPP (Purchasing Power Parity) terms. India's $\mathrm{CO}_{2}$ emissions per capita are well below the world's average. The industrial sector is one of the largest consumers of commercial energy in India, accounting for $42 \%$ of the country's total commercial energy use during 2004-05. Therefore, the fuel switch from fossil fuel to green energy (renewable sources of energy) is considered one of the untapped technological options which will help not only in reducing dependence on hydrocarbon resources but will also address to the threat of "Climate Change" [4].

Pulp and Paper Industry in India is considered to be one of the highly polluting industries, and consumes large amount of energy and water in its various unit operations. The main challenge before the industry is to evolve strategies on effective energy conservation to become cost competitive and compliance of wastewater discharge standards stipulated by the regulatory authorities [5].

M/s Tamil Nadu Newsprint and Papers Ltd. (TNPL), Karur, India, generates 40,000 to 45,000 $\mathrm{m}^{3}$ wastewater during various operations of pulp and paper manufacturing process and treats the same in the open anaerobic lagoons, followed by activated sludge process, to achieve desired BOD/COD reductions. However, the Green House Gases (GHG) viz., Methane was getting released to the atmosphere due to uncontrolled anaerobic reaction in the lagoon. In the open anaerobic lagoon treatment system, the methane rich biogas generated by the uncontrolled anaerobic degradation of organic compounds was not captured; instead it was released directly to the atmosphere. To prevent the release of methane, use of biogas as in-house renewable energy was necessary. Therefore, the TNPL installed anaerobic bio-reactors based upon Upflow Anaerobic Sludge Blanket (UASB) Process to treat the bagasse wash water (BWW) in place of conventional anaerobic lagoon. BWW is generated from the bagasse yard and bagasse washing. This full scale plant was only commissioned after successfully testing the anaerobic process at the pilot plant level.

In this work, the performance of the plant has been studied in order to examine the techno-commercial viability of the anaerobic treatment process for further replication of such plants in the country as information on large size anaerobic digestors/reactors is not available in the open literature.

\section{Effluent Characteristics}

The bagasse received from the sugar mills having $2 \%$ - 3\% residual sugar is stored in the open bagasse yard by wet bulk storage method (made into slurry by mixing with water for forming compact pile) to preserve the quality for a period of 3 to 9 months. This facilitates washing off the residual sugars in the bagasse. The effluent generated form bagasse washing, during the receipt and during reclaiming operation, has relatively high BOD/ COD, low volume and easily biodegradable organic wastes. Thus, it has been treated in the UASB reactor [6][8].

The plant was designed for the average flow, with adequate buffer to take care of the maximum levels indicated in Table 1 and was based on the consideration that the effluent is free from chlorinated compounds. Since the $\mathrm{pH}$ of the raw effluent is in the range of 4.5 - 7.2, neutralization was done by using Milk of Lime (MOL).

Table 1. Average characteristics of bagasse wash wastewater.

\begin{tabular}{ccccc}
\hline Parameters & & & Value & Maximum \\
& Unit & Minimum & Average & 500 \\
Flow Rate & $\mathrm{m}^{3} / \mathrm{hr}$ & 400 & $5.5-6.0$ & 4000 \\
pH & - & & 6000 & 4500 \\
BOD & ppm & 3000 & 800 & 8500 \\
COD & ppm & 5000 & 3500 & 4000 \\
Suspended Solids & ppm & 600 & 3000 & 4000 \\
\hline
\end{tabular}


Accordingly, this leads to 20\% COD reduction due to precipitation and the solids get settled in the Primary Clarifier. Therefore, the actual effluent parameters to the inlet of UASB Reactor are as mentioned in Table 2.

The characteristics of treated bagasse wash water after UASB Reactor was as indicated in the Table 3.

\section{Design, Process Layout and Description of the Biomethanation Plant for Treatment of Bagasse Wash Effluent}

The plant has been designed to handle 12,000 $\mathrm{m}^{3} /$ day of bagasse wash water having average $6000 \mathrm{mg} / \mathrm{l} \mathrm{COD}$ concentration with a hydraulic retention time of 20 hours and maximum organic loading rate of around $5.75 \mathrm{~kg}$ $\mathrm{COD} / \mathrm{m}^{3} /$ day. The process flow diagram is depicted in Figure 1 .

The bagasse wash water generated in the bagasse yard is received into an equalization tank from bagasse clarifier by gravity. The variations in the flow rate and the organic loadings are dampened in the equalization tank. Wash water treatability is enhanced, because shock loadings are minimized and $\mathrm{pH}$ is stabilized to certain extent. The effluent is mixed by means of recirculation pumps to keep the constituents in mixed and homogeneous conditions and to keep the TSS in suspension. This ensures a constant hydraulic and organic loading on the subsequent process units including the biological system. The Equalization Tank was designed for 4 hours HRT.

The effluent then flows to a neutralization tank where the wash water is neutralized using Milk of Lime to raise the $\mathrm{pH}$ from 4.0 - 4.5 to 6.5 - 7.0. After neutralization, the wastewater is taken into a clarifier to settle the suspended solids. The settled sludge is taken to sludge pit and then to a Decanter Centrifuge to thicken solids. The thickened sludge is then solar dried and used as fuel in the boiler.

The clarified wastewater from clarifier is then taken to buffer tank where nutrients, such as, Urea and DAP are added. From buffer tank the wastewater is fed to two UASB reactors through reactor feed pumps. The treated effluent from the reactors is sent to activate sludge process for further treatment. Biogas generated in the reactor is passed through foam trap and sediment trap and stored in gas holder. From the gas holder the gas is pumped to lime kiln by using gas blowers.

\section{Performance of the Plant}

Based on the data monitored, performance of the plant is presented in the Table 4.

Table 2. Average characteristics of bagasse wash wastewater received from primary clarifier.

\begin{tabular}{ccccc}
\hline \multicolumn{2}{c}{ Parameters } & & & Value \\
\hline & Unit & Minimum & Average & Maximum \\
Flow Rate & $\mathrm{m}^{3} / \mathrm{hr}$ & 400 & 500 & 600 \\
$\mathrm{pH}$ & - & & $6.8-7.2$ & $2800-3200$ \\
$\mathrm{BOD}_{5}$ & $\mathrm{ppm}$ & 4800 & 400 \\
COD & $\mathrm{ppm}$ & $\mathrm{ppm}$ & \\
\hline
\end{tabular}

Table 3. Average characteristics of bagasse wash water received from UASB reactor

\begin{tabular}{|c|c|c|c|c|}
\hline \multicolumn{2}{|c|}{ Parameters } & \multirow[b]{2}{*}{ Minimum } & \multicolumn{2}{|c|}{ Value } \\
\hline & Unit & & Average & Maximum \\
\hline Flow Rate & $\mathrm{m}^{3} / \mathrm{hr}$ & 400 & 500 & 600 \\
\hline $\mathrm{pH}$ & - & & $6.5-7.0$ & \\
\hline $\mathrm{BOD}_{5}$ & ppm & & $280-300$ & \\
\hline COD & ppm & & 720 & \\
\hline Suspended Solids & ppm & & $<400$ & \\
\hline
\end{tabular}




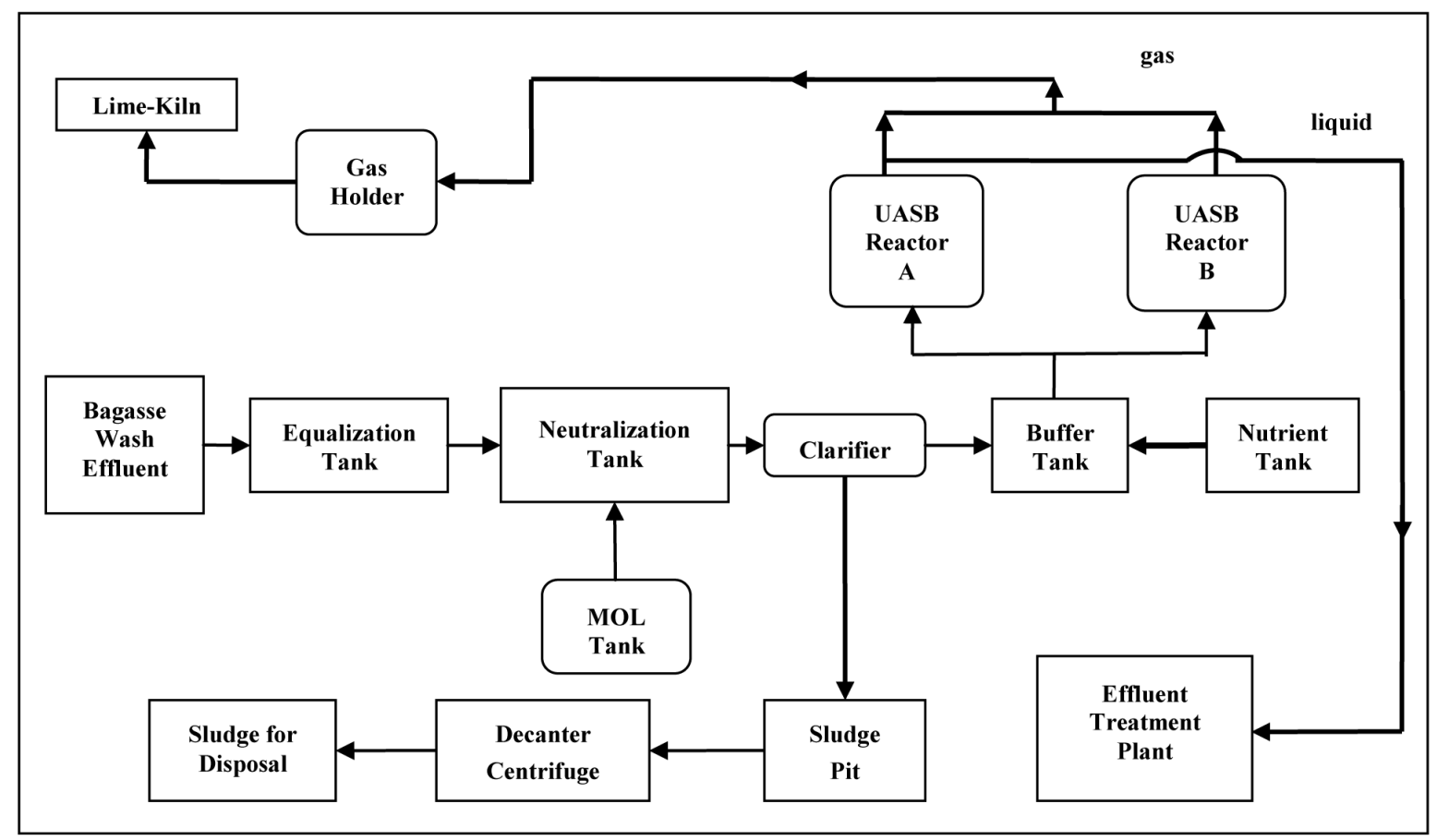

Figure 1. Process flow diagram.

Table 4. Performance of the plant.

\begin{tabular}{ccc}
\hline Description & Unit & Values \\
\hline Raw Effluent inlet & $\mathrm{m}^{3} / \mathrm{day}$ & $9000-10,000$ \\
COD & $\mathrm{ppm}$ & $5000-6000$ \\
COD load & $\mathrm{t} / \mathrm{day}$ & $21.60-32.00$ \\
COD reduction & $\%$ & $80-85$ \\
Organic load to the reactors & $\mathrm{kg} / \mathrm{m}^{3} / \mathrm{d}$ & $2.10-3.20$ \\
Gas production factor & $\mathrm{m}^{3} / \mathrm{kg} \mathrm{COD}_{\mathrm{r}}$ & 0.52 \\
Gas generated & $\mathrm{m}^{3} / \mathrm{d}$ & 13,000 \\
\hline
\end{tabular}

\section{Project Emissions}

The Project activity involves forced $\mathrm{CH}_{4}$ extraction due to change in the treatment process of BWW from open anaerobic lagoon to accelerated $\mathrm{CH}_{4}$ generation in a closed reactor. The captured $\mathrm{CH}_{4}$ has been utilized as a fuel substitute in the lime kiln, replacing the fossil fuel (furnace oil). Accordingly the total project emissions have been estimated following the UNFCCC approved methodology (AM0022 version04) [9] [10] and are as under:

Baseline Emissions from Open Lagoon as per actual data

Project Emissions from Open Lagoon as per actual data $47930.91 \mathrm{tCO}_{2 \mathrm{e}} /$ year

Emission Reduction from Open Lagoon $9586.18 \mathrm{tCO}_{2 \mathrm{e}} /$ year

Baseline Emissions from Furnace Oil usage (Fossil Oil) $38344.73 \mathrm{tCO}_{2 \mathrm{e}} /$ year

Emission Reductions from Project $4900.07 \mathrm{tCO}_{2 \mathrm{e}} /$ year $43245.00 \mathrm{tCO}_{2 \mathrm{e}} /$ year

\section{Financial Analysis of the Project}

The financial analysis of the project [11] has been done by taking into consideration following facts.

1) Savings in furnace oil consumption in lime kiln; 
2) Extra streams of revenue due to Certified Emission Reductions (CERs); and capital subsidy from the Govt. of India (Ministry of New and Renewable Energy also provides capital subsidy @Rs. 100 lakh/MWeq. (or 12,000 cu.m biogas per day) under the Programme on "Recovery of Energy from Industrial Wastes" for the year 2011-12 [12]. As per condition stipulated in the scheme, this entire capital subsidy amount is released to the beneficiary's loan account in the lending Financial Institutions/Banks for the purpose of offsetting the loan amount, only after commissioning of the project).

\subsection{The Financial Analysis Is Based on the Certain Key Parameters and Assumptions as Given Below}

\section{Total Cost of the Project MNRE/UNDP-GEF Grant}

1) Average Biogas Generation

2) Savings in Furnace Oil Consumption in lime Kiln

3) Price of Furnace Oil

4) Savings against reduction in Consumption of Furnace Oil

5) No. of Operation Days

Savings against reduction

In consumption

\section{Other Assumptions}

1) Repair \& Maintenance Cost @ 2\% on the Cost of Fixed Assets with 5\% annual increment;

2) Labour Cost of Rs. 65.00 lakh per annum with $5 \%$ annual increment;

3) Cost of Power-Rs. 26.50 lakh (without any future increment);

4) Chemicals for operation-Rs. 140.60 lakh with $2.5 \%$ annual increment;

5) Rate of Interest for Term Loan-12.5\%;

6) In addition to the above, an adhoc General and Administrative Expenses of Rs. 5.00 lakh per annum (with $5 \%$ annual increment) has been provided;

7) Savings in Furnace Oil Consumption and CER have been considered as income for the purpose of financial projections;

8) Annual savings in Furnace Oil Consumption in value is Rs. 693.00 lakh and Income from CERs is Rs. 312 lakh (after providing for 7.5\% towards expenses, fees etc. and considering a minimum Unit Rate of Euro 12/ CER, Exchange Rate 1 Euro = Rs 65);

9) Depreciation as per Company's Act, Depreciation as per Income Tax Act and Income Tax have been provided at the prescribed rates;

10) Price of Furnace Oil, No. of CERs and Selling rate of CERs have been presumed as fixed during the loan repayment period of 7 years ( 1 year implementation +6 years from the date of commencement of operation); and

11) MNRE Financial Assistance is to be released upon successful commissioning of the Biomethanation Plant.

\subsection{Breakups of Project Costs}

The breakup of the project costs considered for analysis is as under:

\section{Hard Cost}

Land \& Land Development ${ }^{*}$

Civil, Mechanical, Electrical \& Instrumentation (EPC)

Miscellaneous Fixed Assets

Design \& Detailed Engineering

Contingency Provision for Cost Escalation

Sub-total: Hard Cost

Soft Cost

Pre-operative Expenses

IDC

\section{Rs. (lakhs)}

Nil

715.00

30.00

64.00

20.23

829.23

18.00

84.88 
Preliminary Expenses

Sub-total: Soft Cost

Margin for Working Capital

Total

*Land already procured.

Means of Finance

Rs. (lakhs)

Term Loan

679.00

Promoters Contribution

291.47

970.47

2.33

$30.03 \%$

Debt Equity Ratio
Promoter's Contribution to Project Cost

Fixed Assets Coverage Ratio

\subsection{Financial Analysis Was Done for Following Options}

Scenario-I: $70 \%$ of the Project Cost as loan from FIs, 30\% as equity from the promoter and without considering CDM benefits.

Scenario-II: $70 \%$ of the Project Cost as loan from FIs, 30\% as equity from the promoter and with CDM benefits.

Scenario-III: $70 \%$ of the Project Cost as loan from FIs, 30\% as equity including MNRE subsidy towards equity and without CDM benefits.

Scenario-IV: $70 \%$ of the Project Cost as loan from FIs, 30\% as equity including MNRE subsidy towards equity and CDM benefits.

Scenario-V: In case MNRE subsidy of Rs. 108.33 lakh released for offsetting the loan upon commissioning of the Project (i.e. after one year) and without CDM benefits.

Scenario-VI: In case MNRE subsidy of Rs. 108.33 lakh released for offsetting the loan upon commissioning of the Project (i.e. after one year) and with CDM benefits.

Simple Payback period, IRR and DSCR for various scenarios are summarized in Table 5.

From the Table 5, it is evident that the investment on such projects is viable as far as the financial performance is concerned without any additional financial incentives. However, in the current policy regime where Govt. incentives as well as CDM benefits are also available, investment in such projects further improves the financial indicators-payback period of 1 year and 6 months and excellent Gross DSCR of 3.35 (Net DSCR of 4.23) and IRR value of 61.50 Per cent. It is also evident from the analysis that release of entire Govt. subsidy towards offsetting the loan amount is more attractive from the project financing point of view in comparison to when it is released towards equity of the project developer.

\section{Conclusion}

The treatment of Bagasse Wash Water through anaerobic treatment process not only reduces the $\mathrm{CO}_{2}$ emission in the atmosphere due to capturing of methane-a clean fuel, but also reduces the consumption of fossil fuel. The financial analysis also shows that the investment in such projects is very attractive. The financial indicators

Table 5. Results of analysis of six scenarios.

\begin{tabular}{|c|c|c|c|c|c|c|c|}
\hline \multirow{2}{*}{ S. No. } & \multirow{2}{*}{ Financial Indicators } & \multicolumn{6}{|c|}{ Scenario } \\
\hline & & $\mathbf{I}$ & II & III & IV & $\mathbf{V}$ & VI \\
\hline 1 & Simple Payback Period & $\begin{array}{l}2 \text { years \& } \\
9 \text { months }\end{array}$ & $\begin{array}{l}1 \text { year } \& \\
8 \text { months }\end{array}$ & $\begin{array}{l}2 \text { years \& } \\
9 \text { months }\end{array}$ & $\begin{array}{l}1 \text { year } \& \\
8 \text { months }\end{array}$ & $\begin{array}{l}2 \text { year } \& \\
5 \text { months }\end{array}$ & $\begin{array}{l}1 \text { year } \& \\
6 \text { months }\end{array}$ \\
\hline 2 & Post Tax IRR on Project Cost & $32.90 \%$ & $57.00 \%$ & $32.90 \%$ & $57.00 \%$ & $36.60 \%$ & $61.50 \%$ \\
\hline 3 & Gross DSCR (Overall) & 1.94 & 3.20 & 1.94 & 3.20 & 2.02 & 3.35 \\
\hline 4 & Net DSCR (Overall) & 2.35 & 4.18 & 2.35 & 4.18 & 2.40 & 4.23 \\
\hline
\end{tabular}


such as DSCR, Payback period and IRR analysis justify that investments in such projects has a very attractive rate of return and reduces project financing risk of the Financial Institutions. Certified Emission Reductions (CERs) provide extra streams of revenue to make the adoption of anaerobic treatment of BWW lucrative and further reduce the payback periods of the investment initiatives.

\section{Acknowledgements}

Authors are grateful to the Ministry of New and Renewable Energy, Govt. of India, New Delhi, for providing financial assistance for this research work.

\section{References}

[1] Central Electricity Authority, Ministry of Power, Government of India, New Delhi. www.cea.nic.in

[2] Ministry of Power, Government of India, New Delhi. www.powermin.nic.in

[3] (2006) Integrated Energy Policy—Report of the Expert Committee, Planning Commission. Government of India, New Delhi.

[4] (2008) National Action Plan on Climate Change. New Delhi. www.pmindia.nic.in/climate_change.htm

[5] Rintala, J.A., Jain, V.K. and Kettunen, R.H. (1999) Comparative Status of the World-Wide Commercially Available Anaerobic Technologies Adopted for Biomethanation of Pulp \& Paper Mills Effluents. Proceedings of the 4th International Conference on Pulp \& Paper Industry, New Delhi, 14-16 December 1999.

[6] (2006) Green Energy from Wastes. MNRE, New Delhi.

[7] Metcalf and Eddy (1991) Wastewater Engineering Treatment Disposal and Reuse. 3rd Edition. Tata McGraw Hill Edition, New Delhi.

[8] APHA (1998) Standard Methods for the Examination of Water and Wastewater. 20th Edition, American Public Health Association, Washington DC.

[9] AM0022: Avoided Wastewater and On-Site Energy Use Emissions in the Industrial Sector-Version 4.0. http://cdm.unfccc.int/methodologies/DB/BM4NZO7YAH9373G9P0UZHN6G1XM3IW/view.html

[10] (2006) Korat Waste to Energy (KWTE) Project in Thailand. Eco Securities Ltd. http://www.ecosecurities.com

[11] Brennan, D. (1998) Process Industry Economics-An International Perspective. Institution of Chemical Engineers, Rugby.

[12] (2011) Programme on Recovery of Energy from Industrial Wastes. http://www.mnre.gov.in/adm-approvals/energyiw-2011-12.pdf 